Canadian Journal of Soil Science Revue canadienne de la science du sol

\title{
MICRONUTRIENT CONCENTRATIONS VARY BETWEEN PEAT- MINERAL MIX AND SUBSTRATES IN REVEGETATED SITES IN THE ALBERTA OIL SANDS
}

\begin{tabular}{|r|l|}
\hline Journal: & Canadian Journal of Soil Science \\
\hline Manuscript ID & CJSS-2016-0130.R3 \\
\hline Manuscript Type: & Article \\
\hline Date Submitted by the Author: & $30-$ Oct-2017 \\
\hline Complete List of Authors: & $\begin{array}{l}\text { Manimel Wadu, Mihiri; University of Alberta, Renewable Resources } \\
\text { Chang, S.; University of Alberta }\end{array}$ \\
\hline Keywords: & $\begin{array}{l}\text { aqueous speciation, available micronutrient, deficiency, extractability, } \\
\text { overburden }\end{array}$ \\
\hline
\end{tabular}

SCHOLARONE $^{\text {"N }}$

Manuscripts 


\title{
MICRONUTRIENT CONCENTRATIONS VARY BETWEEN PEAT-MINERAL MIX AND SUBSTRATES IN REVEGETATED SITES IN THE ALBERTA OIL SANDS
}

Short title: Micronutrients in reclaimed oil sands soils

\author{
Mihiri C.W. Manimel Wadu and Scott X. Chang*
}

442 Earth Sciences Building, Department of Renewable Resources, University of Alberta, Edmonton, Alberta, Canada T6G 2E3

*Corresponding author. Tel.: +1 780 492-6375; Fax: +1 780 492-1767

E-mail address: manimelw@ualberta.ca / mihiri.wadu@gmail.com (M. Manimel Wadu), Scott.chang@ualberta.ca (S. X. Chang).

Submitted to: Canadian Journal of Soil Science 


\begin{abstract}
Adequate supply of micronutrients is essential for plant growth in reclaimed sites in the Athabasca oil sands region. The objectives of this study were to determine boron, iron, manganese, copper and zinc concentrations in peat mineral mix (PMM), tailings sand (TS) and overburden (OB) materials and to assess whether lodgepole pine (Pinus contorta) planted on PMM over TS and white spruce (Picea glauca) planted on PMM over OB had low foliar micronutrient concentrations. Micronutrient concentrations determined using $\mathrm{LiNO}_{3}$ and Mehlich3 extractions were different between PMM and TS in the pine sites while only $\mathrm{LiNO}_{3}$ extractable boron was different between PMM and OB in the spruce sites $(p<0.05)$. Micronutrient concentrations varied in the order of boron $>$ iron $>$ manganese $>$ zinc $>$ copper in all soil layers with concentrations ranging from 0.04 to $39.56 \mu \mathrm{g} \mathrm{g}^{-1}$. The low foliar concentration of copper in pine and spruce was consistent with low $\mathrm{LiNO}_{3}$ extractable copper in the soil in both the pine and spruce sites. We conclude that the availability of micronutrients such as copper can become a potential limitation for revegetation of white spruce but not lodgepole pine. Further studies on soil management for improving $\mathrm{Cu}$ availability in reclamation materials are needed for improving the growth of spruce in reclaimed soils.
\end{abstract}

Keywords: aqueous speciation, available micronutrient, deficiency, extractability, overburden, tailings sand 


\section{INTRODUCTION}

Oil sands mining in northeast Alberta caused a growing anthropogenic footprint since 1967 (Gosselin et al. 2010; Schindler 2010). On-going land reclamation in this area in the past 25 years aims to achieve the equivalent land capability to that existed pre-disturbance. During initial land reclamation operations, landforms are created using either tailings sand (TS) or fine-textured overburden material $(\mathrm{OB})$ as lower layers or substrates that is covered by approximately $0.2-0.5$ $\mathrm{m}$ of an organic matter rich cover soil which is typically a peat-mineral mix (PMM; a mixture of salvaged peat and surface mineral soils) due to peat material being readily available in the area. Tailings sand is the by-products of the surface mining and oil sands extraction processes while OB is the geologic material lying above the economically mineable oil sands and includes Pleistocene clay deposits and Cretaceous deposits with relatively high alkalinity and salinity-sodicity (Fung and Macyk 2000). Chemical and physical constraints in some reclaimed sites such as low water and nitrogen $(\mathrm{N})$ availabilities and high salinity (Duan et al. 2015a) challenge the recreation of a sustainable ecosystem. Although investigation on macronutrient status of reclaimed sites has been given significant attention in the past, the availability of micronutrients in reclaimed sites is poorly understood. A recent investigation on the foliar elemental composition of jack pine in the Athabasca oil sands region (AOSR) showed that boron (B), iron (Fe) and zinc ( $\mathrm{Zn})$ concentrations significantly increased with proximity to the major oil sands operations (Proemse et al. 2016), but the soil micronutrients were not studied. Although the role of $\mathrm{B}, \mathrm{Fe}$, manganese $(\mathrm{Mn})$, copper $(\mathrm{Cu})$ and $\mathrm{Zn}$ as indicators of air pollutants (Percy et al. 2013) were revealed, the influence of soil micronutrients on tree nutrition in the AOSR remains to be investigated. 
Boron, $\mathrm{Fe}, \mathrm{Mn}, \mathrm{Cu}$ and $\mathrm{Zn}$ are essential micronutrients that play important roles in biochemical reactions related to plant growth. Although micronutrients are needed in trace amounts, deficiencies of those micronutrients in plants directly impact photosynthesis causing low dry matter production. Boron shortage affects many metabolic processes which ultimately impacts photosynthetic function (Blevins and Lukaszewski 1998) while Fe is an integral part of chlorophyll that is involved in photosynthesis (Marschner 2012). Manganese is involved in photosynthetic $\mathrm{O}_{2}$ evolution (Hill reaction) in the chloroplast (Rutherford 1989) while $\mathrm{Cu}$ deficiency results in decreased photosynthetic electron transport (Mizuno et al. 1982). Zinc is essential for chlorophyll synthesis, including the activation of several enzymes and oxidoreduction reactions (Alloway 2008). Also, micronutrients are involved in various enzymes and other physiologically active molecules associated with cell wall development, respiration, enzyme activities and N fixation (Rengel 2003; Schulin et al. 2010). Apart from the direct effect of low micronutrient availability in the soil, ratios between foliar micro- and macronutrients in tree species were found to be important for maintaining optimal leaf physiology (Sobrado 2014).

Land reclamation markedly changes soil physical, chemical and biological functions (Naeth et al. 2011; Farnden et al. 2013; Jung et al. 2014; Li et al. 2014) and available micronutrient contents in the reclaimed soil were found to be closer to or greater than that in soils under natural conditions after more than eight years after reclamation (Li et al. 2013).

Development of toxic levels of available B following reclamation has been observed in some soils (Rhoades et al. 1970), whereas B deficiency is identified in soils that are highly leached (Borkakati and Takkar 2000). Plant establishment and growth in fly ash basin was limited by high $\mathrm{pH}$, and the consequent deficiencies of $\mathrm{Fe}, \mathrm{Mn}, \mathrm{Cu}$, and $\mathrm{Zn}$ (Haynes 2009) and the availability of these nutrients varied considerably with different land reclamation practices (Li et al. 2013). As 
such, possible micronutrient limitations in re-vegetation should be studied to ensure successful land reclamation.

Plant availability of micronutrients in the soil depends on soil $\mathrm{pH}$, redox potential, texture, the quantity and quality of organic matter, mineral composition, temperature, and water regime (Panuccio et al. 2009) and therefore, soils vary widely in their ability to supply micronutrients for optimal plant growth. Due to the differences in the origin and nature of PMM, OB and TS, it is possible that micronutrient availability in reclaimed sites vary between the surface and substrate layers and may also depend on the soil reconstruction strategy (i.e., PMM over OB or PMM over TS). Associations with functional groups of natural organic matter affect bioavailability, toxicity, and mobility of micronutrients in the soil and thus organic matter-rich soils, such as peats are likely to have low available B, Mn, Cu and $\mathrm{Zn}$ (Alloway 2008). Humified organic matter in peat soils might form solid-phase complexes with metal ions leading to micronutrient deficiencies in plants (Andriesse 1988) suggesting possible micronutrient deficiencies in PMM. High bulk density and salinity in OB layer can lead to low available water storage capacity (Duan et al. 2015a) which might have a direct impact on macronutrient availability in OB regardless the positive relation between clay and silt fraction of soil and the micronutrient mobility (Tisdale et al. 1995). In addition, coarse-textured TS has been identified as a poor growth medium due to low cation exchange capacity and low clay and organic matter contents (Fung and Macyk 2000). Furthermore, high pH in reclaimed soils (Howat 2000) is also more likely to cause nutrient deficiencies (Zhang and Zwiazek 2016). Therefore, there is an urgent need for research on micronutrient availability and potential deficiencies in reclaimed soils to achieve successful revegetation. 
This study was conducted in some reclaimed sites in the AOSR to examine the variation in microelement (B, Fe, $\mathrm{Mn}, \mathrm{Cu}$ and $\mathrm{Zn}$ ) concentrations in different reclamation materials (i.e., PMM, OB and TS) and tree species to answer the following questions: 1) what are the differences among PMM, OB and TS in terms of micronutrient concentrations determined using $\mathrm{LiNO}_{3}$ and Mehlich-3 extractions? 2) how different soil properties in PMM, OB and TS are related to the extractable micronutrient concentrations in different soil materials? and 3) do the tree species, i.e., lodgepole pine (Pinus contorta) and white spruce (Picea glauca) growing in reclaimed sites experience micronutrient deficiency? Our hypotheses are that 1) the concentrations of extractable micronutrients in TS and OB is greater than that of PMM due to the low organic matter content in the substrate, due to the micronutrient complexation potential of the peat contained in PMM, and 2) based on the foliar micronutrient concentrations (critical values), tree species experience micronutrient deficiencies when they are planted on reclaimed sites with either TS or OB as the substrate. We expect that the current study on the micronutrient status of pine and spruce stands will provide new information on micronutrient management for revegetated sites in the AOSR.

\section{MATERIALS AND METHODS}

\section{Site description}

Study sites were located $22 \mathrm{~km}$ north of Fort McMurray $\left(56^{\circ} 59^{\prime} \mathrm{N}\right.$ and $\left.111^{\circ} 32^{\prime} \mathrm{W}\right)$ in northeastern Alberta, Canada. The study area was characterized by a continental boreal climate having short and cool summers and long and cold winters. The mean annual temperature from 1971 to 2000 was $0.7^{\circ} \mathrm{C}$ while the mean annual precipitation for the same period was $455.7 \mathrm{~mm}$. The study area was reclaimed from an open-pit mining site to upland forests. The sites were 
reconstructed using PMM as a cover soil above substrates such as TS or OB materials. Lodgepole pine was planted on PMM over TS while white spruce was planted on PMM over OB sites (Jung et al. 2014; Duan et al. 2015a). The different stands of lodgepole pine were planted between 1991 and 1996 while white spruce was planted between 1982 and 1992. Details on site characteristics and understory plant communities are given in Jung et al. (2014) and Duan et al. (2015a).

\section{Experimental design and soil sampling}

Six pine sites and six spruce sites were selected for soil sampling. At each site, a 10 x $10 \mathrm{~m}$ plot was set up for soil sampling. Soil samples were collected from PMM and the substrate at each site in July 2012. Soil samples were collected by depth in each site. The top $20 \mathrm{~cm}$ of PMM and the upper $20 \mathrm{~cm}$ of the substrate, measured from the PMM and substrate interface, were collected using an auger in five randomly selected locations within each plot to obtain a composite PMM or substrate sample. The thickness of the PMM layer in pine and spruce sites varied in the range of 12-30 cm and 11-48 cm, respectively (Duan et al. 2015a). When the thickness of the PMM was less than $20 \mathrm{~cm}$, the entire PMM layer was sampled. All soil samples were placed in plastic bags and taken back to the laboratory. The soil samples were air-dried and used for chemical and physical analyses.

\section{Measurements of soil properties}

Soil texture was determined using the hydrometer method (Gee and Or 2002). Soil pH was measured in deionized water using a digital DMP-2 mV/pH meter (Thermo Fisher Scientific Inc., Waltham, MA) with soil to water ratio of 1:2 (w:v). The electrical conductivity of soil samples was measured using an AP75 portable waterproof conductivity/TDS meter (Thermo Fisher 
Scientific Inc., Waltham, MA) using $30 \mathrm{~g}$ of air-dried soil in $60 \mathrm{~mL}$ deionized water after shaking for $1 \mathrm{~h}$ at $25^{\circ} \mathrm{C}$ and filtration through Whatman No. 42 filter papers (Dellavalle 1992). Air-dried soil samples were ground with a ball mill and used to analyze for total $\mathrm{C}$ and $\mathrm{N}$ concentrations with a Carlo Erba NA 1500 elemental analyzer (Carlo Erba Instruments, Milano, Italy) at the Lethbridge Research Centre of Agriculture and Agri-Food Canada (Duan et al. 2015a). Available $\mathrm{N}$ was measured by extracting soil samples with $0.5 \mathrm{~mol} \mathrm{~L}^{-1} \mathrm{KCl}$ at 1:3 soil to solution ratio (w:v), shaking at $250 \mathrm{rpm}$ on a mechanical shaker for $1 \mathrm{~h}$ and then filtering through Whatman No. 42 filter papers. Concentrations of $\mathrm{NH}_{4}{ }^{+}-\mathrm{N}$ and $\mathrm{NO}_{3}{ }^{-}-\mathrm{N}$ in the extracts were analyzed using the steam distillation method using a Kjeldahl distillation system (Vapodest 20, C. Gerhardt, Königswinter, Germany) (Bremner 1996). Water extractable K was analyzed using a Perkin Elmer Optima 3000 DV inductively coupled plasma mass spectrometer (ICP-MS) (PerkinElmer Inc., Shelton, CT) after extraction with deionized water at 1:2 of soil to water ratio (w:v) and filtration.

To determine Mehlich-3 extractable B, Fe, Mn, Cu, and $\mathrm{Zn}$, a $2.5 \mathrm{~g}$ of soil was placed in a centrifuge tube, and $25 \mathrm{~mL}$ of Mehlich-3 solution $\left(0.2 \mathrm{~mol} \mathrm{~L}^{-1} \mathrm{CH}_{3} \mathrm{COOH}, 0.25 \mathrm{~mol} \mathrm{~L}^{-1} \mathrm{NH}_{4} \mathrm{NO}_{3}\right.$, $0.015 \mathrm{~mol} \mathrm{~L}^{-1} \mathrm{NH}_{4} \mathrm{~F}, 0.013 \mathrm{~mol} \mathrm{~L}^{-1} \mathrm{HNO}_{3}, 0.001 \mathrm{~mol} \mathrm{~L}^{-1}$ EDTA) was added to the centrifuge tube. The mixture was then shaken for 5 min on a mechanical shaker at 120 strokes per minute, and the extract was filtered using Whatman No. 40 filter paper (Mehlich 1984). Micronutrient concentrations were measured using PerkinElmer Optima 3000 DV inductively coupled plasma mass spectrometer (ICP-MS) (PerkinElmer Inc., Shelton, CT). The $\mathrm{LiNO}_{3}$ extraction was carried out to determine plant available micronutrient concentrations in soil samples (Abedin et al. 2012). A $2.5 \mathrm{~g}$ of soil was extracted using $10 \mathrm{~mL}$ of $0.01 \mathrm{~mol} \mathrm{~L}^{-1} \mathrm{LiNO}_{3}$ solution by shaking for $24 \mathrm{~h}$ at 120 strokes per minute. The extractant was centrifuged at $1770 \times \mathrm{g}$ for $10 \mathrm{~min}$ and filtered through Whatman 44 filter papers and analyzed by ICP-MS for B, Fe, Mn, $\mathrm{Cu}$ and $\mathrm{Zn}$ concentrations. 


\section{Speciation of micronutrients}

Soil samples $(0.5 \mathrm{~g})$ were extracted using $50 \mathrm{~mL}$ of Milli-Q water in polyethylene centrifuge tubes. The tubes were shaken on a mechanical shaker for $60 \mathrm{~min}$ at $40 \mathrm{rpm}$ at room temperature and then centrifuged at $2767 \times \mathrm{g}$ for $10 \mathrm{~min}$. The supernatant was extracted with a $0.45 \mu \mathrm{m}$ cellulose nitrate filter to obtain the soil extract (Fernández-Caliani et al. 2009).The soil extract was analyzed for anions (sulfate, nitrate, chloride and fluoride) using a Dionex ion chromatograph. The bicarbonate determination was done by volumetric titration with $0.02 \mathrm{~mol} \mathrm{~L}^{-}$ ${ }^{1} \mathrm{HCl}$. The B, Fe, Mn, $\mathrm{Cu}$ and $\mathrm{Zn}$ concentrations in the solution were analyzed by ICP-MS. Micronutrient speciation was performed using CHEAQUES Next, a Windows program for calculating chemical equilibria in aquatic systems (Verweij 2007).

\section{Plant sampling and foliar micronutrient analysis}

In October 2012, five representative trees were randomly selected in each plot with each species growing in one substrate type. One branch from the upper one-third of the live crown of each tree was collected to form a composite branch sample for each plot. Branch samples were placed in paper bags and taken back to the laboratory. The foliage from each branch was separated into current-year and 1-year-old needles. After washing twice using distilled water, current-year needles were oven-dried at $65^{\circ} \mathrm{C}$ for $24 \mathrm{~h}$ or until constant weight is achieved. Three hundred needles were randomly selected and weighed and ground to pass through a $0.15 \mathrm{~mm}$ sieve in preparation for nutrient analyses. Total $\mathrm{P}, \mathrm{K}, \mathrm{B}, \mathrm{Fe}, \mathrm{Mn}, \mathrm{Cu}$ and $\mathrm{Zn}$ in needles were analyzed with the ICP-MS after digestion using concentrated $\mathrm{HNO}_{3}$ and $30 \% \mathrm{H}_{2} \mathrm{O}_{2}$ on a digestion block at 125 
${ }^{\circ} \mathrm{C}$ for $4 \mathrm{~h}$ (Campbell and Plank 1998) and total $\mathrm{N}$ in needles was determined with a Carlo Erba NA 1500 elemental analyzer.

\section{Statistical analysis}

Principle component analysis (PCA) was performed using the PROC FACTOR procedure in SAS 9.2. The first PCA was applied to the $\mathrm{LiNO}_{3}$ and Mehlich-3 extractable micronutrient data from both pine and spruce sites. The second PCA was conducted on $\mathrm{LiNO}_{3}$ and Mehlich-3 extracted micronutrients and soil properties. Principal components (PC) were derived from a correlation matrix and variables were transformed to z-scores prior to PCA. The final component structure was unrotated and included only PCs with eigenvalues greater than unity (Kaiser 1960). The first PCA was conducted to illustrate the similarity and/or differences among PMM, TS and OB based on extractable (i.e., both Mehlich-3 and $\mathrm{LiNO}_{3}$ ) micronutrient concentrations. The purpose of the second PCA was to determine what soil properties mainly governed Mehlich-3 and $\mathrm{LiNO}_{3}$ extractable micronutrient concentrations. Comparison of means of $\mathrm{LiNO}_{3}$ and Mehlich-3 extracted micronutrient concentrations was performed using the Tukey's multiple comparison test. An $\alpha$ value of 0.05 was chosen to indicate statistical significance in all analyses. All statistical analyses were performed using the SAS software (SAS 9.2, SAS Institute Inc., Cary, NC).

\section{RESULTS AND DISCUSSION}

\section{Differences of soil properties among reclamation materials}

Soil $\mathrm{pH}$ was alkaline in both PMM and substrate in most sites except for some TS samples (Table 1) and was about two units greater than the soil $\mathrm{pH}$ in native boreal ecosystems (Howat 2000). Soil $\mathrm{pH}$ was not significantly different between the PMM and the substrate in each site 
type (pine vs spruce sites). Higher $\mathrm{pH}$ in PMM than in natural peat materials was attributed to the clay-rich, calcium-absorbing mineral soil in the PMM and the windblown deposits from nearby exposed tailings (Rowland 2008). Also, saline-sodic overburden and tailings sand with a high sodium concentration can have Na translocate to the PMM by the capillary action (Jorenush and Sepashkah 2003) and form sodium bicarbonate due to the reaction with water resulting in a significant increase in soil pH when hydrolyzed (Marschner 2012). However, EC in the pine and spruce sites were less than the critical values of $4 \mathrm{dS} \mathrm{m}^{-1}$ for causing salt stress in trees growing in the AOSR (Howat 2000), but high EC was the unique characteristic that differentiated spruce sites from pine sites based on the substrate type. The EC in PMM and OB was 2-fold and 13-fold greater than the PMM and TS, respectively.

Peat-mineral mix in pine and spruce sites had greater N, P, K and total carbon content than the TS or OB substrate in each site type as expected (Table 1). The high total carbon (C) content and the low bulk density in PMM in both sites are indicative of the higher organic matter content in PMM as compared to the substrate in each site. Soil organic carbon content in PMM is highly correlated with microbial respiration rate, enzyme activities, cation exchange capacity and bulk density (Kong et al., 1980). Conversely, low carbon content in OB and TS caused a significant decrease in phenoloxidase activities and increased the dissimilarities of microbial communities between natural and reclaimed sites (Dimitriu et al. 2010).

The low cation exchange capacity, the absence of clay and the extremely low total $\mathrm{C}$ content in TS together were reflective of the poor nutrient status in TS as a substrate compared to OB (Table 1). Such undesirable soil chemical properties of TS can adversely affect plant growth (Fung and Macyk 2000). High bulk density in TS was caused by the sandy texture of TS, while soil compaction by heavy equipment or highly compacted reconstructed materials caused high 
bulk density in $\mathrm{OB}$ with high clay content. Water storage is also influenced to a large extent by soil organic carbon content in PMM (Duan et al. 2015a). Increasing organic matter content increases the amount of water held at field capacity more than that held at the permanent wilting point, thereby increasing the water holding capacity in the soil (Hudson 1994). Unlike PMM, low water holding capacity and water availability in the TS were attributed to the high macroporosity (Jung at al. 2014) that can affect nutrient availability.

\section{Distribution of micronutrient concentrations varies among PMM, TS and OB}

There was no significant relationship between micronutrient concentrations from $\mathrm{LiNO}_{3}$ and Mehlich-3 extractions for most of the elements analyzed $(p=0.221)$, except for B in PMM in spruce sites. The independence of the micronutrient concentrations measured by the two extractants indicates that they are not extracting micronutrients from the same pools in PMM, TS, and $\mathrm{OB}$. The greater $\mathrm{B}$ concentration measured by $\mathrm{LiNO}_{3}$ than by Mehlich-3 indicates that the former is a strong extractant for B in reclamation materials due to possible exchange reactions between nitrate for $\mathrm{H}_{2} \mathrm{BO}_{3}{ }^{-}$. Although Mehlich-3 is a versatile extractant for extraction of multielements, the superior extractability of $\mathrm{B}$ by $\mathrm{LiNO}_{3}$ over Mehlich-3 in reclamation material has not been reported elsewhere to the best of our knowledge. The greater extractability of cationic micronutrients by Mehlich-3 is expected since it is a weak acid that is thought to remove a number of cations in the exchangeable fraction, soil solution and a part of the adsorbed or complexed forms (Cancela et al. 2002). Specifically, $\mathrm{Fe}, \mathrm{Mn}, \mathrm{Cu}$ and $\mathrm{Zn}$ are extracted by ammonium and the EDTA in the Mehlich-3 extractant. On the other hand, $\mathrm{LiNO}_{3}$ is a neutral electrolyte that does not change soil $\mathrm{pH}$ during extraction and provides a realistic estimate of phytoavailable trace element concentrations under natural $\mathrm{pH}$ conditions as compared with other more aggressive extractants (Abedin et al. 2012). 
The extractability of all five micronutrients by each extractant was in the same order for samples from PMM and substrates in pine and spruce sites: $\mathrm{Fe}>\mathrm{Mn}>\mathrm{B}>\mathrm{Zn}>\mathrm{Cu}$ (Table 2). A similar order of $\mathrm{LiNO}_{3}$ extractable $\mathrm{Fe}, \mathrm{Mn}, \mathrm{Zn}$ and $\mathrm{Cu}$ was also found in soils collected from a reclaimed mining area ( $\mathrm{Li}$ et al. 2013). There are significant variations in $\mathrm{LiNO}_{3}$ and Mehlich-3 extractable micronutrient concentrations in the PMM and in both substrates (Table 2). Mehlich-3 extractable concentrations of $\mathrm{Fe}, \mathrm{Mn}, \mathrm{Cu}$ and $\mathrm{Zn}$ were greater than $\mathrm{LiNO}_{3}$ extractable micronutrient concentrations in pine and spruce sites. The PCA of the $\mathrm{LiNO}_{3}$ and Mehlich-3 extractable micronutrient concentrations of all soil samples provides a clear differentiation of PMM and the substrate in each of the pine and spruce sites (Figure 1). The first axis in the PCA accounted for $44 \%$ of the variation in the data set and differentiated PMM and TS of pine sites. The second axis in the PCA explained $20 \%$ of the variation in the data set and differentiated PMM and $\mathrm{OB}$ of spruce sites. A greater difference was found between PMM and the substrate in pine sites than in spruce sites, since most of the PMM and OB samples showed a positive correlation with PC1 while TS samples were negatively correlated with PC1 differentiating TS largely from PMM in pine sites. Such results are expected due to the contrasting differences in both physical and chemical properties between PMM and TS in comparison with PMM and OB (Table 1).

Even though the extractability of micronutrients was similar in PMM, TS and OB, the available fraction of the total extractable pool (i.e., $\mathrm{LiNO}_{3}$ extractable micronutrient concentration expressed as a percent of the Mehlich-3 extractable micronutrient concentration) varied depending on the micronutrient and the soil layer. For instance, only 0.1 to $5.8 \%$ of Mehlich-3 extractable Fe was available whereas 2.5 to $62 \%$ of the extractable $\mathrm{Zn}$ was available (Table 2), indicating the different ability of PMM, TS and OB to retain micronutrients. This emphasizes the importance of exploiting micronutrients in reclamation materials using different extractants since $\mathrm{Mn}, \mathrm{Cu}$ and $\mathrm{Zn}$ 
are also heavy metals with a potential environmental risk when present at high concentrations. Copper and $\mathrm{Zn}$ were the least extractable micronutrients in both site types. Copper has been identified as the least mobile micronutrient among the studied micronutrients in forest soils (Mortvedt et al. 1991) since $\mathrm{Cu}$ reside mostly in unavailable forms and has lower mobility and bioavailability than Zn (Hickey and Kittrick 1984). The Mehlich-3 extractable Cu concentration was greater in pine and spruce sites than the $\mathrm{Cu}$ concentration of $0.19 \mu \mathrm{g} \mathrm{g}^{-1}$ found in natural forest soils (Entry et al. 1987) indicating high amounts of $\mathrm{Cu}$ in reclaimed soils. The large difference between $\mathrm{LiNO}_{3}$ and Mehlich-3 extractable Fe and Mn concentrations in pine and spruce sites indicated that both elements resided mainly in a pool that is not readily available. Watersoluble and exchangeable Fe are plant-available forms of $\mathrm{Fe}$, but in organic soils $50 \%$ of the Fe was found in the organic and the sulfide fractions (Hoffman and Fletcher 1978).

Our hypothesis of substrates having greater micronutrient concentrations than PMM is valid only for the pine sites where $\mathrm{LiNO}_{3}$ extractable micronutrient concentrations were significantly greater in TS than in PMM for most of the micronutrients studied. In pine sites, $\mathrm{LiNO}_{3}$ extractable Fe, Mn and B concentrations were significantly greater in TS than in PMM (Table 2) likely due to low organic matter and relatively low $\mathrm{pH}$ (Table 1) despite the reported negative impact of TS on plant growth (Fung and Macyk 2000). Such findings suggest the potential of the TS substrate to provide micronutrients for tree growth in reclaimed lands in the AOSR. The $\mathrm{LiNO}_{3}$ extractable $\mathrm{B}$ concentration in TS and OB samples were significantly greater than that in the PMM in each site type with the lowest $\mathrm{LiNO}_{3}$ extractable B found in pine sites (Table 2). Soil moisture status is the main environmental factor affecting the availability of B to plants, and that relates to the lowest $\mathrm{LiNO}_{3}$ extractable B in PMM in pine sites where water limitation has been identified (Duan et al. 
2015). Moreover, relatively high $\mathrm{pH}$ in PMM could lead to a greater absorption of B (Barrow 1989) in PMM than the substrates in both sites.

\section{Soil properties governing $\mathrm{LiNO}_{3}$ and Mehlich-3 extractable micronutrient concentrations vary depending on the site type.}

A PCA was used to derive some relationships between soil properties and micronutrient concentrations in PMM in both sites due to the high Mehlich-3 extractable micronutrient concentration in PMM. However, some significant correlations between $\mathrm{LiNO}_{3}$ extractable micronutrient concentrations and soil properties of pine and spruce sites were found for PMM but not for TS and OB (Supplementary Table S1). For pine sites, PC1 and PC2 explained 39\% and $30 \%$ of the variance in the data set, respectively, indicating that both PCs are equally important (Table 3). In general, soil reaction seems to be the most important factor affecting $\mathrm{LiNO}_{3}$ extractable micronutrient concentrations (except $\mathrm{Fe}$ ) in pine sites while Mehlich-3 extractable pool (except Zn) were related to soil physical conditions associated with total $\mathrm{C}$ and bulk density. In spruce sites, $\mathrm{PC} 1$ accounted for $63 \%$ of the variation in the data set and exemplified that soil attributes such as total $\mathrm{C}$ content, $\mathrm{pH}, \mathrm{EC}$ and bulk density influenced both $\mathrm{LiNO}_{3}$ and Mehlich-3 extractable cations in spruce sites.

The above results showed that micronutrient concentrations in different pools largely depend on more than one soil factor, and that further studies on the behavior of these elements in reclamation materials are warranted. Although soil physical and chemical properties were comparable in PMM in two site types, the underlying mechanisms for micronutrient extractability varied, partly due to the effect of the vegetation type as shown by specific relationships between soil and foliar nutrients in the pine and spruce sites (Supplementary Table S2). This calls for site- 
specific fertilizer studies even though the reclamation material is of the same origin. The interrelationships between micro- and macronutrients under low water availability and high salinity (Duan et al. 2015a) might further aggravate the effect of low available macronutrients on tree growth. The Mehlich-3 extractable $\mathrm{Cu}$ in PMM showed a significantly negative relationship with available $\mathrm{N}$ in both site types while available $\mathrm{P}$ and water extractable $\mathrm{K}$ were also negatively related to the Mehlich-3 $\mathrm{Cu}$ in PMM of spruce sites (Supplementary Table S2).

\section{Micronutrient speciation modeling}

There were some differences in speciation among micronutrients, but speciation of a particular micronutrient did not vary significantly between pine and spruce sites regardless of the material (PMM or substrate) being compared (Figure 2). Such similarity in aqueous speciation of micronutrients is likely due to the similar soil $\mathrm{pH}$ between PMM and substrates. A greater number of aqueous species was found for $\mathrm{Cu}$ than for $\mathrm{Mn}$ and $\mathrm{Zn}$ in soil extracts (Figure 2). Species containing hydroxyl group comprised a major fraction of dissolved $\mathrm{Fe}, \mathrm{Cu}$, and $\mathrm{Zn}$. Other anions such as nitrate, phosphate, sulfate, and chloride were not candidates for forming ion pairs or complexes with $\mathrm{Fe}, \mathrm{Mn}, \mathrm{Cu}$ and $\mathrm{Zn}$ as is reflected in the low concentration (i.e., $<1 \%$ ) of these anions in the soil extract (data not shown). Subtle amounts of free ions of micronutrients were present in the soil extract showing the restricted mobility of free ions in the soil (Figure 2). Hence, cation exchange may not be the primary pathway of replenishing the available pool of micronutrients in soils.

The aqueous speciation of $\mathrm{Cu}$ and $\mathrm{Zn}$ was similar as both existed mainly in the hydrolyzed form in the soil extract. Both precipitation and adsorption of $\mathrm{Zn}$ and $\mathrm{Cu}$ increase as the soil $\mathrm{pH}$ increases, causing low availability of $\mathrm{Zn}$ and $\mathrm{Cu}$ as compared to Fe and $\mathrm{Mn}$ (Mortvedt et al. 
1991). Moreover, both $\mathrm{Cu}^{2+}$ and $\mathrm{Zn}^{2+}$ form strong complexes with functional groups associated with the humic acid component of peat (Dissanayake and Weerasooriya, 1981). In the neutral pH range, about $70 \%$ of $\mathrm{Cu}$ was hydrolyzed but precipitation of $\mathrm{Cu}(\mathrm{II}) \mathrm{OH}_{2}$ may not be the reason for the low $\mathrm{LiNO}_{3}$ extractable $\mathrm{Cu}$ in $\mathrm{PMM}$ since $\mathrm{Cu}$ may precipitate at high $\mathrm{pH}$ range and high solution concentration of $\mathrm{Cu}^{2+}$ (Harter 1983). However, when compared with $\mathrm{Cu}$, precipitation of $\mathrm{Zn}(\mathrm{OH})_{2}$ is a possibility due to much greater $\mathrm{LiNO}_{3}$ extractable $\mathrm{Zn}$ concentration (Table 2). The general order of affinity of the cationic micronutrient with organic matter was reported as $\mathrm{Cu}>\mathrm{Fe}$ $>\mathrm{Mn}>\mathrm{Zn}$ (Park et al. 2011) confirming the high affinity of $\mathrm{Cu}$ to be retained by the organic fraction due to the formation of $\mathrm{Cu}$ complexes in the soil (Agbenin 2010) and inner-sphere complexation of $\mathrm{Cu}(\mathrm{II})$ (Karlsson et al. 2006). The greater proportion of complexes and ion pairs of $\mathrm{Cu}$ than those of $\mathrm{Mn}$ and $\mathrm{Zn}$ in the soil extract indicates the high potential of $\mathrm{Cu}$ to react with organic matter in reclaimed soils (Figure 2). Adsorption reactions between $\mathrm{Cu}^{2+}$ and humic fractions of Sphagnum peat moss (Gardea-Torresdey et al. 1996) lower the free $\mathrm{Cu}^{2+}$ ion concentration seven orders of magnitude below the total $\mathrm{Cu}^{2+}$ concentration (Benedetti and Van Riemsd ijkel 1995).

Speciation of Fe in soils was determined as FeIII $(\mathrm{OH})_{4}^{-}(76 \%)$ and $\mathrm{FeIII}(\mathrm{OH})_{3(\mathrm{aq})}(24 \%)$ while $\mathrm{B}$ was present as free $\mathrm{H}_{2} \mathrm{BO}_{3}^{-}{ }_{(\mathrm{aq})}$ and $\mathrm{H}_{(}\left(\mathrm{H}_{2} \mathrm{BO}_{3}\right)_{(\mathrm{aq})}$. The presence of hydrolysis species of $\mathrm{Fe}(\mathrm{III})$ indicated that soil $\mathrm{pH}$ was the main factor determining Fe species in soil solution (Lindsay and Schwab 1982). In pine sites, $92 \%$ of $\mathrm{B}$ was present as free $\mathrm{H}_{2} \mathrm{BO}_{3}{ }^{-}$(aq) in $\mathrm{PMM}$ while only $\mathrm{H}\left(\mathrm{H}_{2} \mathrm{BO}_{3}\right)_{(\mathrm{aq})}$ was present in TS. In spruce sites, $99 \%$ of B was present as $\mathrm{H}_{(}\left(\mathrm{H}_{2} \mathrm{BO}_{3}\right)_{(\mathrm{aq})}$ in PMM, while $90 \%$ of B was present as free $\mathrm{HBO}_{3(\mathrm{aq})}^{-}$in OB. High Mehlich-3 extractable B in TS and OB (Table 2) is supported by the presence of $\mathrm{H}_{(}\left(\mathrm{H}_{2} \mathrm{BO}_{3}\right)_{(\mathrm{aq})}$ in two substrates. Relatively low $\mathrm{B}$ in PMM compared to substrates could be due to the fraction of B associated with various soil 
components including adsorbed and occluded B in mineral phase which is not readily available in the soil solution (Kot 2000; Kot et al. 2012).

\section{Foliar micronutrient concentrations and the ratio of foliar macro- to micronutrients}

The foliar analysis provides an index of the amount of nutrients taken up by the trees and this method is considered to be most useful for identifying severely deficient nutrients (Carter 1992) and also as an indicator of soil nutrient availability (Brockley 2001). In both species, the foliar concentration of micronutrients in current year's foliage varied in the order of $\mathrm{Fe}>\mathrm{Mn}>\mathrm{B}$ $>\mathrm{Zn}>\mathrm{Cu}$ (Figure 3). Nutrient deficiencies in pine and spruce were determined using the critical micronutrient concentrations reported for Pinus and Picea species as shown in Figure 3 (Beaton et al. 1965; Ingestad 1958; Stoate 1950). The foliar $\mathrm{Cu}$ concentration in spruce ranged from 1.7 to $6.9 \mu \mathrm{g} \mathrm{g}^{-1}$ indicating that $\mathrm{Cu}$ was deficient in four of six sites studied. Therefore, out of the five micronutrients, only $\mathrm{Cu}$ was identified to be low in spruce trees, consistent with the low availability of $\mathrm{Cu}$ in PMM and OB that could lead to reduced tree growth (Mizuno et al. 1982). This partially supports the second hypothesis. However, symptoms of $\mathrm{Cu}$ deficiency are less specific than that of other micronutrients (Reuther and Labanauskas 1966) and might not be revealed unless foliar samples were monitored. Both pine and spruce had sufficient B, Fe, Mn and $\mathrm{Zn}$ and also $\mathrm{Cu}$ in pine regardless of the varying extractability of these nutrients in PMM and substrate in each site type.

As shown in a previous study, application of a complete fertilizer (i.e., including B, Fe, Mn, $\mathrm{Cu}$, and $\mathrm{Zn}$ ) in the same study sites did not affect foliar micronutrient concentrations in both species (Duan et al. 2015b). Such findings are expected for B, Fe, Mn and Zn since both pine and spruce had sufficient foliar concentrations of these micronutrients. The lack of response to $\mathrm{Cu}$ 
application suggests possible retention of applied $\mathrm{Cu}$ in reconstructed soils, similar to that reported in James and Barrow (1981) and McBride (1981). Even though strong correlations between shoot tissue and $\mathrm{LiNO}_{3}$ extractable concentrations of trace elements have been reported (Abedin et al. 2012), such relationships were not found in the present study. Such discrepancy between our study and Abedin et al. (2012) may reflect the differences between results from a field study and a greenhouse study.

Foliar analysis information can also be used to monitor foliar nutrient balance (Brockley 2001). Since nutrient ratios have shown to be promising in identifying nutrient deficient sites (Hockman and Allen 1990; Valentine and Allen 1990), nutrient ratios may be especially important if one or both of the elements are near deficiency levels (Marschner 2012). Although pine and spruce were grown over differently reconstructed sites, the ratios of macronutrient:micronutrient were comparable for most of the nutrients studied (Figure 4). Therefore, pine and spruce exhibited the capability to maintain leaf nutrient balances while growing on soils with different levels of macro- and micronutrient availabilities. The ratios between $\mathrm{N}, \mathrm{P}, \mathrm{K}$ and $\mathrm{Cu}$ were high as expected. Regardless the N limitation in spruce sites (Duan et al. 2015a), ratios between foliar N and micronutrients were comparable to that in pine sites except for $\mathrm{Cu}$. However, N/Cu, N/B and N/Fe were considerably low in both pine and spruce compared the upper threshold values reported for these two species (Brockley and Simpson 2004) which might have an effect on tree growth. For instance, $\mathrm{N}$ metabolism is abnormal in the leaves from a copper-deficient tree and abnormal amounts of complex $\mathrm{N}$ compounds were formed at the expense of the carbohydrate reserves (Gilbert et al. 1946). Moreover, fertilizer induced Cu deficiency (Amponsah et al. 2005) may further aggravate the low $\mathrm{Cu}$ level in spruce during fertilizer application to overcome low $\mathrm{N}$ 
availability in spruce sites (Duan et al. 2015). An improper N-Cu balance might also cause a disorder known as "ammoniation" by heavy application of $\mathrm{N}$ fertilizers (Camp et al. 1939).

\section{Implications for Land Reclamation}

Our results demonstrated low $\mathrm{Cu}$ availability in PMM in spruce sites and that adds to the previous findings on the soil nutrient limitations of PMM (e.g., Hemstock et al. 2010; Duan et al. 2015), indicating the necessity for enhancing $\mathrm{Cu}$ availability in reclaimed soils. The frequent occurrence of $\mathrm{Cu}$-deficiency in peat soils reclaimed for agriculture has led to the term "reclamation disease" for this condition (Welch et al. 1991). Since Cu reacts with inorganic and organic compounds within the soil (James and Barrow 1981; McBride 1981), monitoring the beneficial effects on tree form and height development as well as changes in $\mathrm{Cu}$ availability in the soil upon fertilizer application is needed.

The time since reclamation exerts a large influence on the content and distribution of available micronutrients in the soil (Li et al. 2013). Although available B, Fe, Mn and Zn concentrations in pine and spruce sites are at sufficiency levels, further monitoring of the availability of those micronutrients in reclaimed sites is worthwhile because weathering, decomposition of organic matter and changes in soil water regime can alter the solubility and availability of micronutrients. Research on the distribution of micronutrients in the surface soil layer during land reclamation showed that $\mathrm{Cu}$ and $\mathrm{Zn}$ move slowly and gradually upwards as water evaporates (Li et al. 2013). This phenomenon can be particularly important for pine sites where high evapotranspiration demand is a possibility (Duan et al. 2015a). Hence, the availability of $\mathrm{Cu}$ and $\mathrm{Zn}$ may be further reduced in pine sites as compared to other micronutrients. The large pool of Mehlich-3 extractable Fe in PMM in both sites is indicative of the potential of Fe being 
released to the soil over the course of time due to the decomposition of organic matter and mineral weathering that could lead to high available Fe in PMM. Available Fe in soil increased and exceeded the available Fe in natural soils as the time since reclamation increased (Li et al. 2013). The increased Fe availability may negatively affect the nutrient balance in vegetation over time A slightly acidic soil $\mathrm{pH}$ and a proper balance with other nutrients will help maintain the optimum $\mathrm{Cu}$ level in spruce sites. Soil $\mathrm{pH}$ between 5 to 6.5 has been identified to be optimal for surface materials for revegetation in boreal forests, particularly for planting coniferous trees, in northern Alberta (Macyk et al. 1993). Soil management to reduce pH in PMM should be taken into consideration when planning reclamation practices to avoid nutrient limitations. Further research on soil reaction mechanisms that control the solubility and mobility of micronutrients in PMM, TS and OB will improve our understanding of the availability of nutrients in reclaimed soils.

\section{ACKNOWLEDGEMENTS}

This study was supported by a Discovery grant from the Natural Science and Engineering Council of Canada (NSERC) and by the Land Reclamation International Graduate School (LRIGS), which was funded by a Collaborative Research and Training Experience (CREATE) grant from the NSERC. Suncor Energy provided logistic support. We thank Dr. Min Duan and Mr. Jason House for providing the soil samples and Dr. Murtaza Jamro and others in the Forest Soils Laboratory for assistance in conducting the fieldwork. We thank the two anonymous reviewers and the associate editor for constructive comments that substantially improved an earlier version of this manuscript. 


\section{REFERENCES}

Abedin, J., Beckett, P. and Spiers, G. 2012. An evaluation of extractants for assessment of metal phytoavailability to guide reclamation practices in acidic soilscapes in northern regions. Can. J. Soil Sci. 92: 253-268.

Agbenin, J. O. 2010. Extractability and Transformation of Copper and Zinc added to tropical savanna soil under long-term pasture. Commun. Soil Sci. Plant. Anal. 41: 1016-1027.

Alloway, B. J. 2008. Micronutrients in crop production: An introduction. In: B. J. Alloway (ed.), Micronutrient deficiencies in global crop production. Dordrecht: Springer. pp. 1-40.

Amponsah, I. G., Comeau, P. G., Brockley, R. P. and Lieffers, V. J. 2005. Effects of repeated fertilization on needle longevity, foliar nutrition, effective leaf area index and growth characteristics of lodgepole pine in interior British Columbia, Canada. Can. J. For. Res. 35: 440451 .

Andriesse, J. P. 1988. Nature and management of tropical peat soils. No. 59. Food And Agriculture Organization of The United Nations, Rome.

Barrow, N. J. 1989. Testing a mechanistic model. X. The effect of $\mathrm{pH}$ and electrolyte concentration on borate sorption by a soil. J. Soil Sci. 40: 427-435.

Beaton, J. D., Brown, G., Speer, R. C., MacRae, I., McGhee, W. P. T., Moss, A. and Kosick, R. 1965. Concentration of micronutrients in foliage of three coniferous tree species in British Columbia. Soil Sci. Soc. Am. Proc. 29: 299-302.

Benedetti M. F. and Van Riemsdijkel, W. H. 1995. Metal ion binding to humic substances: Application of the non-ideal competitive adsorption model. Environ. Sci. Technol., 29: 446-457.

Blevins, D. L. and Lukaszewski, K. M. 1998. Boron in plant structure and function. Annu. Rev. Plant. Physiol. Plant. Mol. Biol. 49: 481-500

Borkakati, K. and Takkar, P. N. 2000. Forms of boron in acid alluvial and lateritic soils in relation to ecosystems and rainfall distribution. Paper presented at Int. Conf. on Management of Natural Resources for Sustainable Agricultural Production in the 21st Century, 12th February 2000, New Delhi, India.

Bremner, J. M. 1996. Nitrogen-Total. In: Sparks, D. L., Page, A. L., Helmke, P. A., Loeppert, R. H., Soltanpour, P. N., Tabatabai, M. A., Johnston, C. T. and Sumner, M. E. (eds.), Methods of Soil Analysis. Part 3-Chemical Methods, Soil Science Society of America Inc., Madison, 10851121. 
Brockley, R. P. 2010. Effects of intensive fertilization on the foliar nutrition and growth of young lodgepole pine forests in the interior of British Columbia. B.C. Ministry of Forests, Victoria. Tech. Report 058.

Brockley, R. P. and Simpson, D. G. 2004. Effects of intensive fertilization on the foliar nutrition and growth of young lodgepole pine and spruce forests in the interior of British Columbia (E.P. 886.13) - establishment and progress report. B.C. Ministry of Forests, Victoria. Tech. Rep. 018.

Camp, A. F., and Fudge, B. R. 1939. Some symptoms of citrus malnutrition in Florida. Univ. Florida Agr. Exp. Sta. Bull. 335.

Campbell, C. R. and Plank, C. O. 1998. Preparation of plant tissue for laboratory analysis. In: Kalra, Y. P. (ed.), Handbook of Reference Methods for Plant Analysis. CRC Press, Boca Raton, Florida, pp. 37-50.

Cancela, R. C., Aparecida de Abreu, C. and Paz-González, A. 2002. DTPA and Mehlich-3 micronutrient extractability in natural soils. Commun. Soil Sci. Plant Anal. 33: 2879-2893.

Carter, R. 1992. Diagnosis and interpretation of forest stand nutrient status. In: Chappell, H. N., Weetman, G. F. and Miller R. E. (ed.), Forest fertilization: sustaining and improving nutrition and growth of western forests. College of Forest Resources, University of Washington, Seattle, Wash. Contribution No.73. pp. 90-97.

Dellavalle, N. B. 1992. Determination of specific conductance in supernatant 1:2 soil:water solution. In: Dellavalle, N. B. (ed.), Handbook on Reference Methods for Soil Analysis. Soil and Plant Analysis Council, Inc. Athens, GA. pp. 44-50.

Jorenush M. and Sepaskhah, A. 2003. Modelling capillary rise and soil salinity for shallow saline water table under irrigated and non-irrigated conditions. Agri. Water Manage. 61:125-141.

Dimitriu, P. A., Prescott, C. E., Quideau, S. A. and Grayston, S. J. 2010. Impact of reclamation of surface-mined boreal forest soils on microbial community composition and function. Soil Biol. Biochem. 42: 2289-2297.

Dissanayake, C. B. and Weerasooriya, S. V. R. 1981. Peat as a metal-trapping material in the purification of industrial effluents. Inter. J. Environ. Stud. 17: 233-238

Duan, M., House, J. and Chang, S. X. 2015a. Limiting factors for lodgepole pine (Pinus contorta) and white spruce (Picea glauca) growth differ in some reconstructed sites in the Athabasca oil sands region. Ecol. Eng. 75: 323-331. 
Duan, M. and Chang S. X. 2015b. Responses of lodgepole pine (Pinus contorta) and white spruce (Picea glauca) to fertilization in some reconstructed boreal forest soils in the oil sands region. Ecol. Eng. 84: 354-361.

Entry, J. A., Stark, N. M. and Loewenstein, H. 1987. Effect of timber harvesting on extractable nutrients in a Northern Rocky Mountain forest soil. Can. J. For. Res. 17: 735-739.

Farnden, C., Vassov, R. J., Yarmuch, M. and Larson, B. C. 2013. Soil reclamation amendments affect long term growth of jack pine following oil sands mining. New For. 44: 799-810.

Fernández-Caliani, J. C., Barba-Brioso, C. and De la Rosa, J. D. 2009. Mobility and speciation of rare earth elements in acid mine soils and geochemical implications for river waters in the southwestern Iberian margin. Geoderma. 149: 393-401.

Fung, M. Y. P. and Macyk, T. M. 2000. Reclamation of oil sands mining areas. In: Barnhisel, R. I., Darmody, R. G., Daniels, W. L. (eds.), Reclamation of Drastically Disturbed Lands. ASA, CSSA and SSSA, Madison, Wisconsin, pp. 755-774.

Gardea-Torresdey, J. L. Tang, L. and Salvador, J. M. 1996. Copper adsorption by esterified and unesterified fractions of phagnum peat moss and its different humic fractions. J. Hazard. Mater. 48: 191-206.

Gee, G. W. and Or, D., 2002. Particle size analysis. In: Dane, J. H., Topp, G. C. (eds.), Methods of Soil Analysis Part 4: Physical Methods. SSSA, Madison, Wisconsin, pp. 255-293.

Gilbert S. G., Sell H. M., Drosdoff M. 1946. The effect of copper deficiency on the nitrogen metabolism and oil synthesis of the tung tree. Plant Physiol. 3: 290-303.

Gosselin, P., Hrudey, S. E., Naeth, M. A., Plourde, A., Therrien, R., van der Kraak, G., and Xu, Z. 2010. The Royal Society of Canada Expert Panel: environmental and health impacts of Canada's oil sands industry. The Royal Society of Canada, The Academies of Arts, Humanities and Sciences of Canada, Ottawa, Ontario

Harter, R. D. 1983. Effect of soil pH on adsorption of lead, copper, zinc and nickel. Soil Sci. Soc. Am. J. 47: 47-51

Haynes, R. J. 2009. Reclamation and revegetation of fly ash disposal sites - Challenges and research needs. J. Environ. Manage. 90: 43-53.

Hemstock, S. S., Quideau, S. A., Chanasyk, D. S. 2010. Nitrogen availability from peat amendments used in boreal oil sands reclamation. Can. J. Soil Sci. 90: 165-175. 
Hickey, M. G. and Kittrick, J. A. 1984. Chemical partitioning of cadmium, copper, nickel, and zinc in soils and sediments containing high levels of heavy metals. J. Environ. Qual. 13: 372-376

Hockman, J. N., and H. L. Allen. 1990. Nutritional diagnoses in loblolly pine stands using a DRIS approach. In Sustained productivity of forest soils: Proc. 7th North Am. Forest Soils Conference, Gessel, S.P., D.S. Lacate, G.F. Weetman, and R.F. Powers (eds.). Univ. British Columbia, Faculty of Forestry Publication, Vancouver, BC, Canada. pp. 500-514

Hoffman, S. J. and Fletcher, W. K. 1978. Selective sequential extraction of Cu, Zn, Fe, Mn, and Mo from soils and sediments. In: J. R. Watterson and P. K. Theoblad. (ed.), Geochemical exploration. IMM Publ. pp. 289-299.

Howat, D. R. 2000. Acceptable Salinity, Sodicity and pH Values for Boreal Forest Reclamation. Alberta Environment, Edmonton, Alberta.

Hudson, B. D. 1994. Soil organic matter and available water capacity. J. Soil Water Conserv. 49: 189-194.

Ingestad, T. 1958. Studies on manganese deficiency in a forest stand. Medd. Stat. Skogsforsk. 48: 20.

James, R. O. and Barrow, N. J. 1981. Copper reactions with inorganic components of soils including uptake by oxide and silicate minerals. In: Loneragan, J. F., Robson, A. D., Graham, R. D. (eds.), Copper in Soils and Plants. Academic Press, Sydney.

Jiang, Y., Zhang, Y. G., Zhou, D., Qin Y. and Liang, W. J. 2009. Profile distribution of micronutrients in an aquatic brown soil as affected by land use. Plant Soil Environ. 55: 468-476.

Jung, K., Duan, M., House, J. and Chang, S. X. 2014. Textural interfaces affected the distribution of roots water, and nutrients in some reconstructed forest soils in the Athabasca oil sands region. Ecol. Eng. 64: 240-249.

Kaiser, H. F. 1960. The application of electronic computers to factor analysis. Edu. Psychol. Meas. 20: 141-151.

Karlsson, T., Persson, P. and Skyllberg, U. 2006. Complexation of copper(II) in organic soils and in dissolved organic matter - EXAFS evidence for chelate ring structures. Env. Sci. Tech. 40: 2623-2628.

Kong, K., Lindsay, J. D. and McGill. W. B. 1980. Characterization of stored peat in the Alberta oil sands area. Environment Canada and Alberta Oil Sands Environmental Research Program 
Database. Alberta Environment, Edmonton, Alberta, Canada.

https://era.library.ualberta.ca/files/5425kc219\#.WOvsMPkrJhF (accessed April. 2017).

Kot, F. S. 2009. Boron sources, speciation and its potential impact on health. Rev Environ. Sci. Biotechnol. 8: 3-28

Kot, F. S. Farran, R., Kochva, M. and Shaviv, A. 2012. Boron in humus and inorganic components of Hamra and Grumusol soils irrigated with reclaimed wastewater. Soil Res. 192: $195-210$.

Li, X. P., Chang, S. X. and Salifu, K. F. 2014. Soil texture and layering effects on water and salt dynamics in the presence of a water table: a review. Environ. Rev. 22: 41-50.

Li, Z., Zhang, Q. and Peng, L. 2013. Distribution characteristics of available trace elements in soil from a reclaimed land in a mining area of north Shaanxi, China. Int. Soil Water Conserv. Res. 1: $65-75$

Lindsay W. L. and Schwab, A. P. 1982. The chemistry of iron in soils and its availability to plants. J. Plant Nutr. 5: 821-840,

Macyk, T. M., Brocke, L. K., Fujikawa, J., Hermans, J. C. and McCoy, D. 1993. Soil quality criteria relative to disturbance and reclamation. Alberta Agriculture, Edmonton, Alberta. pp.56.

Marschner, P. 2012. Marschner's Mineral Nutrition of Higher Plants. Elsevier Ltd., USA.

McBride, M. B. 1981. Forms and distribution of copper in solid and solution phases of soil. In: Loneragan, J. F., Robson, A. D., Graham, R. D. (eds.), Copper in Soils and Plants. Academic Press, Sydney.

Mehlich, A. 1984. Mehlich-3 soil test extractant: a modification of Mehlich-2 extractant. Commun. Soil Sci. Plant Anal. 15: 1409-1416.

Mizuno, N., Inazu, O. and Kamada, K. 1982. Characteristics of concentrations of copper, iron and carbohydrates in copper deficient wheat plants. In: A. Scaife (ed.) Poc. $9^{\text {th }}$. Int. Plant Nutr. Colloq., Warwick, England. 22-27 Aug. 1982. Commonwealth Agric. Bur., Farnham House, Slough, England. pp. 396-399.

Mortvedt, J. J., Cox, F. R., Shuman, L. M. and Welch R. M. (eds.) 1991. Micronutrients in Agriculture - Second Edition. Soil Science Society of America, Madison, Wisconsin, USA 
Naeth, M. A., Wilkinson, S. R., Mackenzie, D. D., Archibald, H. A. and Powter, C. B. 2013. Potential of LFH Mineral Soil Mixes for Land Reclamation in Alberta. Oil Sands Research and Information Network, Edmonton, Alberta, pp. 1-64.

Panuccio, M. R., Sorgonà, A., Rizzo M. and Cacco, G. 2009. Cadmium adsorption on vermiculite, zeolite and pumice: batch experimental studies. J. Environ. Manage. 90: 364-374.

Park, J. H., Lamb, D., Paneerselvam, P., Choppala, G., Bolan N. and Chung, J. W. 2011. Role of organic amendments on enhanced bioremediation of heavy metal(loid) contaminated soils. J. Hazard. Mater. 185: 549-574.

Percy, K. E., Maynard, D. G., Legge, A. H. 2013. Applying the forest health approach to monitoring boreal ecosystems in the Athabasca Oil Sands Region. In: Percy, K. E., (ed.), Alberta Oil Sands: Energy, Industry and the Environment; Elsevier: Amsterdam, The Netherlands, 2013; 11:193-217.

Proemse, B. C., Maynard D. G. and Mayer, M. 2016. Foliage chemistry of Pinus banksiana in the Athabasca Oil Sands Region, Alberta, Canada. Forests. 7: 312-325.

Rengel, Z. 2003. Heavy metals as essential nutrients. In: Prasad M. N. V., Hagemeyer J. (eds.), Heavy Metal Stress in Plants: Molecules to Ecosystems. Springer-Verlag, Berlin, Heidelberg. pp. 93-121.

Reuther, W. and Labanauskas, C. K. 1966. Copper. In: Diagnostic Criteria for Plants and Soils, Univ. Calif., Div. Agr. Sci. pp. 157-179.

Rhoades, J. D., Ingvalson R. D. and Hatcher J. T. 1970. Laboratory determination of leachable soil boron. Soil Sci. Soc. Am. J. 34: 871-875.

Rowland, S. M. 2008. Recreating a functioning forest soil in reclaimed oil sands in northern Alberta, M.Sc. Thesis, Faculty of Forestry, University of British Columbia.

Rutherford, A. W. 1989. Photosystem II, the water splitting enzyme. Trends Biochem. Sci. 14: 227-232.

Schindler, D. 2010. Tar sands need solid science. Nature, 468: 499-501.

Schulin, R., Johnson A. and Frossard E. 2010. Trace Element deficient soils. In: Hooda S. (ed.), Trace Elements in Soils. John Wiley \& Sons Ltd, United Kingdom. pp. 177-197. 
Sobrado, M. A. 2014. Relationship between leaf micro- and macro-nutrients in top canopy trees in a mixed forest in the upper Rio Negro in the Amazon region. Am. J. Plant Sci. 5: 1423-1431.

Stoate, T. N. 1950. Nutrition of the pine. Forestry and Timber Bureau (Australia). Bull. 30.

Tisdale, S. L., Nelson, W. L., Beaton J. D. and Havlin, J. L. 1995. Soil fertility and fertilizer, 5th Ed. Prentice-Hall of India, New Delhi. pp. 684.

Valentine, D. W. and Allen, H. L. 1990. Foliar responses to fertilization identify nutrient limitation in loblolly pine. Can. J. For. Res. 20: 144 -151.

Verweij, W. 2007. Chemical equilibria in aquatic systems-CHEAQS Next-PC calculating program. http://home.tiscali.nl/cheaqs/index.html.

Welch, R. M., Allaway, W. H., House, W. A. and Kubota, J. 1991. Geographic distribution of trace element problems. In: J. J. Mortvedt, F.R. Cox, L.M. Shuman, R.M. Welch (eds.), Micronutrients in Agriculture; SSSA Book Series 4, 2nd edn; Soil Science Society of America, Madison WI, 1991, pp. 31-57.

Zhang W. and Zwiazek, J. J. 2016. Responses of Reclamation Plants to High Root Zone pH: Effects of Phosphorus and Calcium Availability. J. Environ. Qual. 45: 1652-1662. 
2 Table 1. Properties (means with SD in parenthesis) of soils collected from lodgepole pine and white spruce sites selected for this study 3 in the Athabasca oil sands region, Alberta (Duan et al. 2015a).

4

5

\begin{tabular}{|c|c|c|c|c|c|c|c|c|c|c|}
\hline \multirow[b]{2}{*}{$\begin{array}{l}\text { Plant } \\
\text { species }\end{array}$} & \multirow[b]{2}{*}{$\begin{array}{l}\text { Soil } \\
\text { layer }\end{array}$} & \multicolumn{6}{|c|}{ Soil property } & \multirow[b]{2}{*}{$\begin{array}{c}\text { Inorganic } \\
\mathrm{N} \\
\left(\mathrm{mg} \mathrm{kg}^{-1}\right)\end{array}$} & \multirow[b]{2}{*}{$\begin{array}{c}\text { Available } \\
\mathrm{P} \\
\left(\mathrm{mg} \mathrm{kg}^{-1}\right)\end{array}$} & \multirow[b]{2}{*}{$\begin{array}{c}\text { Water } \\
\text { extractable } \\
\mathrm{K} \\
\left(\mathrm{mg} \mathrm{kg}^{-1}\right)\end{array}$} \\
\hline & & $\begin{array}{c}\text { Clay } \\
\left(\mathrm{g} \mathrm{kg}^{-1}\right)\end{array}$ & $\mathrm{pH}$ & $\begin{array}{c}\text { Electrical } \\
\text { conductivity } \\
\left(\mathrm{dS} \mathrm{m}^{-1}\right)\end{array}$ & $\begin{array}{c}\text { Bulk } \\
\text { density } \\
\left(\mathrm{Mg} \mathrm{m}^{-3}\right)\end{array}$ & $\begin{array}{c}\text { Total } \\
\mathrm{C} \\
\left(\mathrm{g} \mathrm{kg}^{-1}\right) \\
\end{array}$ & $\begin{array}{c}\text { Total } \\
\mathrm{N} \\
\left(\mathrm{g} \mathrm{kg}^{-1}\right) \\
\end{array}$ & & & \\
\hline \multirow[t]{2}{*}{ Pine } & PMM & $235(48)$ & $7.80(0.07)$ & $0.98(0.21)$ & $0.95(0.21)$ & $75.77(1.05)$ & $2.57(1.05)$ & $4.16(2.11)$ & $1.56(1.05)$ & $7.22(2.26)$ \\
\hline & TS & $<\mathrm{DL}^{\mathrm{a}}$ & $6.68(1.04)$ & $0.22(0.15)$ & $1.37(0.17)$ & $1.87(0.96)$ & $0.02(0.01)$ & $1.96(0.43)$ & $0.41(0.10)$ & $2.39(0.91)$ \\
\hline \multirow[t]{2}{*}{ Spruce } & PMM & $127(18)$ & $7.69(0.43)$ & $2.27(1.23)$ & $0.89(0.33)$ & $86.15(73.66)$ & $3.61(3.46)$ & $3.41(2.54)$ & $0.80(0.47)$ & $19.25(6.94)$ \\
\hline & OB & $280(43)$ & $7.60(0.19)$ & $3.03(2.17)$ & $1.28(0.15)$ & $40.27(4.57)$ & $0.46(0.11)$ & $1.93(0.52)$ & $0.49(0.17)$ & $11.42(5.19)$ \\
\hline
\end{tabular}

\section{6}

7 Note: Data in table are means of nine replicates

$8 \quad$ a DL stands for detection limit. 
14 Table 2. Micronutrient concentrations in soils collected from lodgepole pine and white spruce 15 sites.

16

\begin{tabular}{llllllll}
\hline $\begin{array}{l}\text { Extraction } \\
\text { method }\end{array}$ & $\begin{array}{l}\text { Tree } \\
\text { species }\end{array}$ & $\begin{array}{l}\text { Soil } \\
\text { layer }^{\mathrm{a}}\end{array}$ & $\mathrm{B}$ & $\mathrm{Fe}$ & $\mathrm{Mn}$ & $\mathrm{Cu}$ & $\mathrm{Zn}$ \\
\hline
\end{tabular}

Micronutrient concentration $\left(\mu \mathrm{g} \mathrm{g}^{-1}\right)$

\begin{tabular}{llllllll}
$\mathrm{LiNO}_{3}$ & Pine & PMM & $17.28 \mathrm{~b}^{\mathrm{b}}$ & $0.30 \mathrm{~b}$ & $0.12 \mathrm{~b}$ & $<\mathrm{DL}^{\mathrm{c}}$ & $0.17 \mathrm{a}$ \\
& & $\mathrm{TS}$ & $33.88 \mathrm{a}$ & $6.67 \mathrm{a}$ & $0.30 \mathrm{a}$ & $<\mathrm{DL}$ & $0.05 \mathrm{~b}$ \\
& \multirow{2}{*}{ Spruce } & PMM & $22.42 \mathrm{~b}$ & 14.07 & 0.54 & $<\mathrm{DL}$ & 0.07 \\
& & OB & $39.56 \mathrm{a}$ & 10.51 & 0.32 & 0.04 & 0.11
\end{tabular}

\begin{tabular}{llllllll} 
Mehlich-3 & Pine & PMM & $2.11 \mathrm{a}$ & $289.24 \mathrm{a}$ & $14.06 \mathrm{a}$ & $1.36 \mathrm{a}$ & $3.01 \mathrm{a}$ \\
& & TS & $0.41 \mathrm{~b}$ & $54.96 \mathrm{~b}$ & $3.80 \mathrm{~b}$ & $0.33 \mathrm{~b}$ & $0.80 \mathrm{~b}$ \\
& \multirow{2}{*}{ Spruce } & PMM & 2.93 & 240.56 & 14.24 & 1.70 & 4.43 \\
& & OB & 3.30 & 221.81 & 33.55 & 1.50 & 4.31
\end{tabular}

Note: Data in table are means of six replicates per treatment.

${ }^{a}$ PMM, TS, and OB stand for peat-mineral soil mix, tailings sand and overburden, respectively.

${ }^{\mathrm{b}}$ Different letters indicate significant differences in micronutrient concentration between PMM

21 and substrate of each site type at $p<0.05$ (i.e., between PMM and TS in pine sites and between

22 PMM and OB in spruce sites).

$23{ }^{\mathrm{c}} \mathrm{DL}$ stands for detection limit.

24

25

26

27 
28 Table 3. Principal components extracted from a correlation matrix based on soil properties and 29 micronutrients in pine and spruce sites.

\begin{tabular}{|c|c|c|c|c|c|}
\hline \multirow{3}{*}{ Variable } & \multirow{3}{*}{ Variable } & \multicolumn{2}{|c|}{ Pine } & \multicolumn{2}{|c|}{ Spruce } \\
\hline & & & & & 31 \\
\hline & & PC1 & PC2 & PC1 & $\mathrm{PC} 2$ \\
\hline \multirow[t]{5}{*}{ Soil properties } & Total C & $-0.75^{a}$ & -0.53 & -0.97 & $0.13^{2}$ \\
\hline & Clay & -0.56 & 0.35 & 0.39 & -0.68 \\
\hline & $\mathrm{pH}$ & 0.51 & 0.65 & 0.91 & -0.20 \\
\hline & $\begin{array}{l}\text { Electrical } \\
\text { conductivity }\end{array}$ & -0.02 & 0.95 & 0.54 & $0.52^{34}$ \\
\hline & Bulk density & 0.97 & 0.15 & 0.93 & -0.135 \\
\hline \multirow{5}{*}{$\begin{array}{l}\text { Mehlich-3 extractable } \\
\text { micronutrients }\end{array}$} & $\mathrm{B}$ & -0.98 & 0.13 & -1.00 & -0.02 \\
\hline & $\mathrm{Fe}$ & -0.93 & 0.15 & -0.82 & -0.34 \\
\hline & $\mathrm{Mn}$ & 0.85 & -0.09 & 0.75 & 0.247 \\
\hline & $\mathrm{Cu}$ & 0.68 & -0.02 & 0.89 & 0.30 \\
\hline & $\mathrm{Zn}$ & -0.26 & 0.65 & -0.81 & $0.35^{38}$ \\
\hline \multirow{7}{*}{$\begin{array}{l}\mathrm{LiNO}_{3} \text { extractable } \\
\text { micronutrients }\end{array}$} & B & 0.13 & $\begin{array}{l}-0.92 \\
\end{array}$ & 0.93 & -0.139 \\
\hline & $\mathrm{Fe}$ & 0.51 & 0.45 & -0.95 & 0.17 \\
\hline & Mn & -0.19 & 0.78 & -0.95 & $0.16^{\circ}$ \\
\hline & $\mathrm{Zn}$ & 0.16 & -0.62 & 0.23 & 0.841 \\
\hline & Eigenvalue & 5.49 & 4.24 & 9.52 & 2.742 \\
\hline & $\%$ Variance & 39.22 & 39.22 & 63.50 & 63.51 \\
\hline & $\begin{array}{l}\text { Cumulative } \\
\text { explanation }\end{array}$ & 30.22 & 69.54 & 18.50 & $82.01^{43}$ \\
\hline
\end{tabular}

$45{ }^{a}$ Values in the table are the correlation of each variable with each principal component. Bold 46 values indicate the strongest associations.

47

48

49

50

51

52

53 


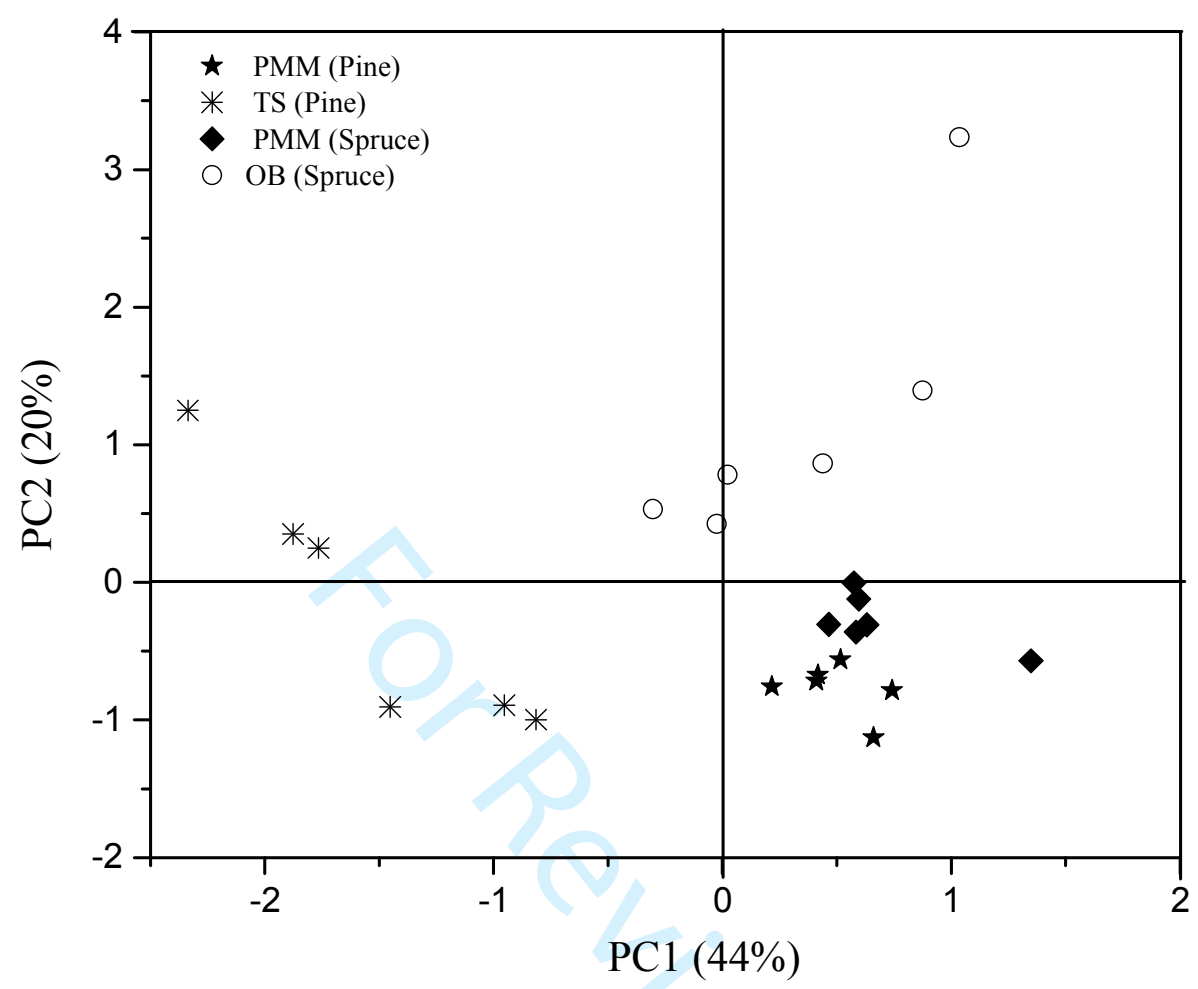

54

55

56 Figure 1. Principal component analysis of the $\mathrm{LiNO}_{3}$ and Mehlich-3 extractable micronutrient

57 concentrations in soils collected from lodgepole pine and white spruce sites selected for this study

58 in the Athabasca oil sands region, Alberta. PMM, TS, and OB stand for peat-mineral soil mix,

59 tailings sand and overburden, respectively.

60

61 


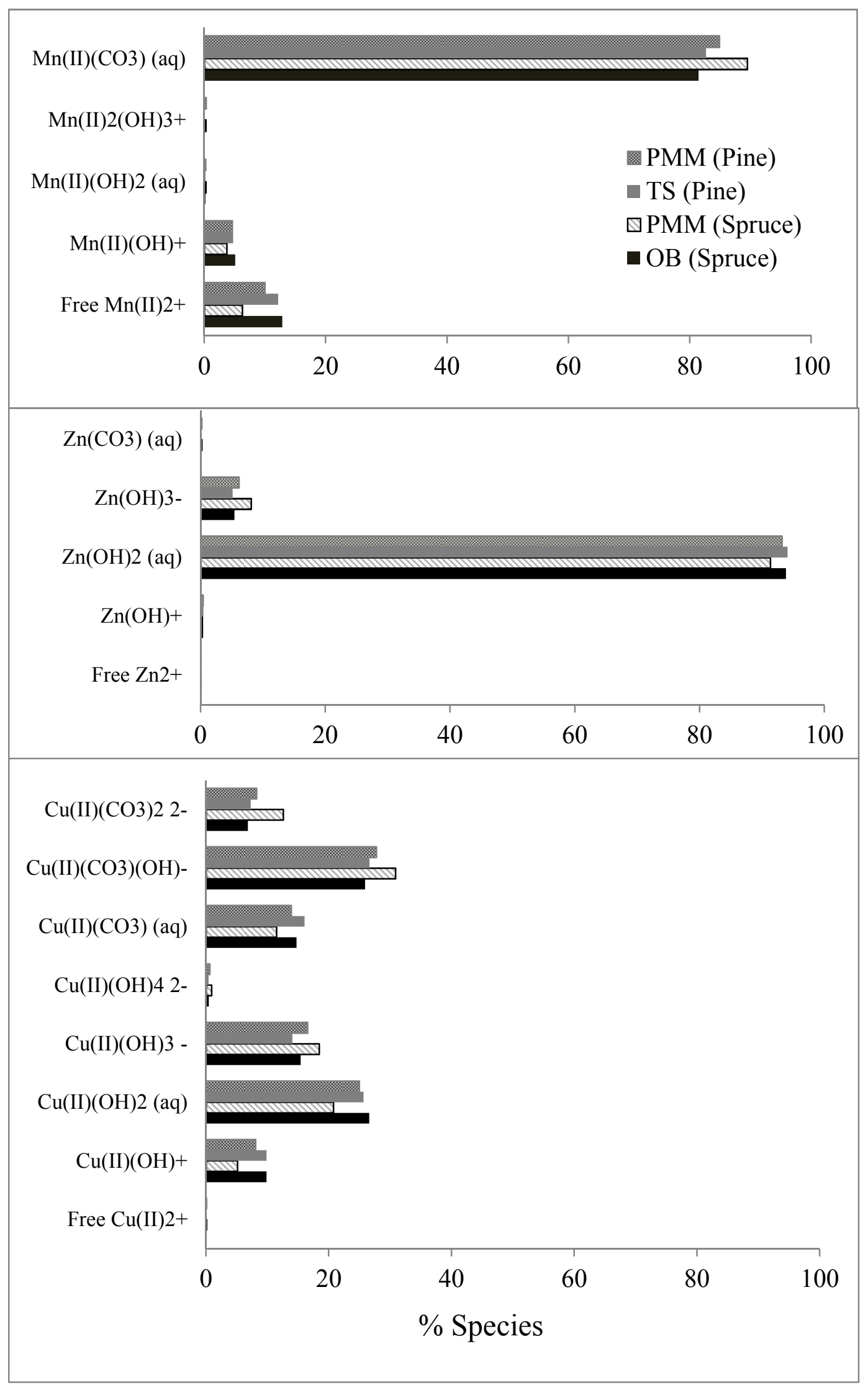


63 Figure 2. Results of $\mathrm{Mn}, \mathrm{Zn}$ and $\mathrm{Cu}$ speciation simulation for solutions extracted from soils in 64 lodgepole pine and white spruce sites selected for this study in the Athabasca oil sands region, 65 Alberta. PMM, TS, and OB stand for peat-mineral soil mix, tailings sand and overburden, 66 respectively.

67

68 


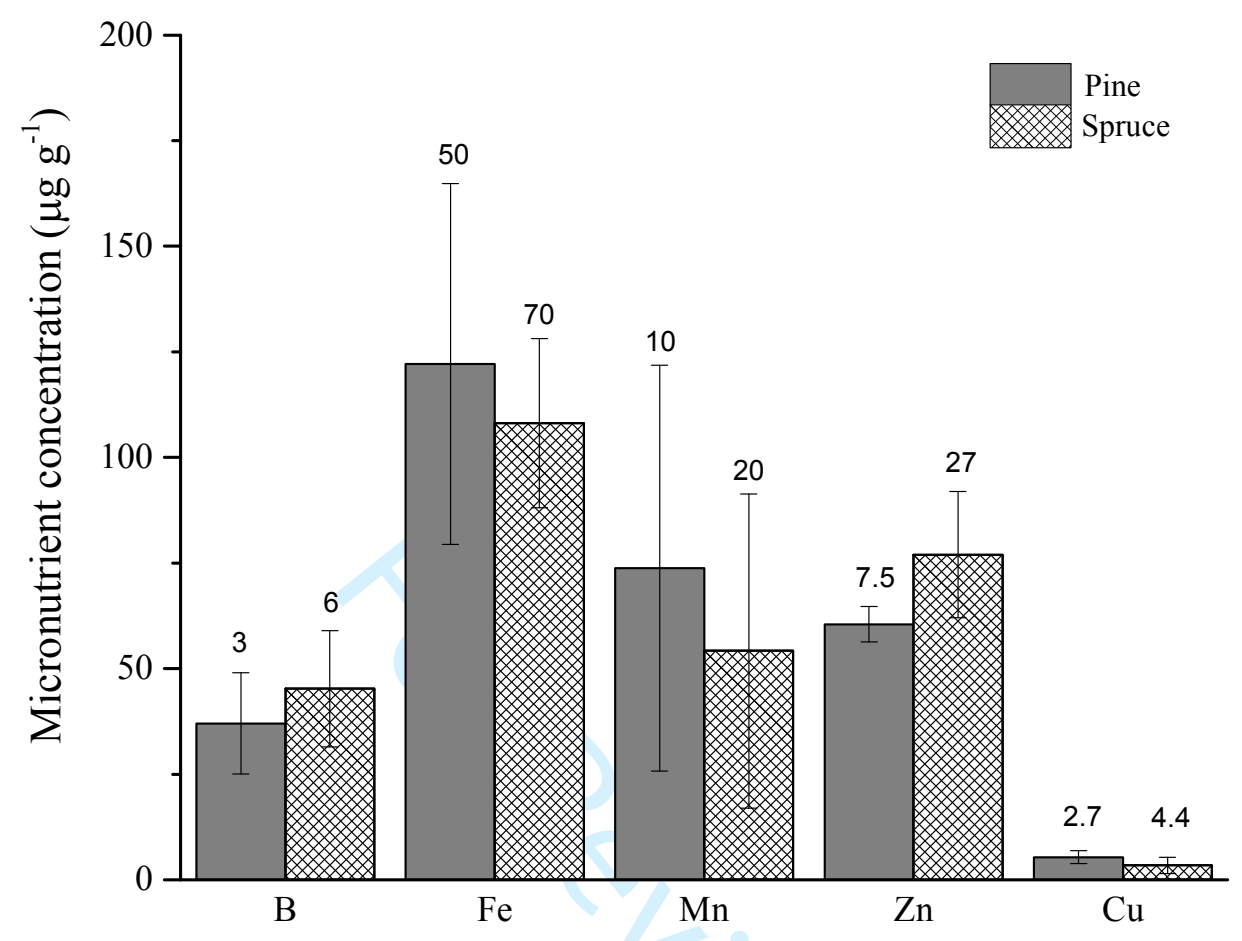

69

70 Figure 3. Foliar micronutrient concentrations (means \pm SD) in lodgepole pine and white spruce.

71 The value above each column is the critical concentration of a particular micronutrient.

72 Concentrations below the critical concentration indicate a deficiency in respective tree species

73 (Beaton et al. 1965; Ingestad 1958; Stoate 1950).

74 


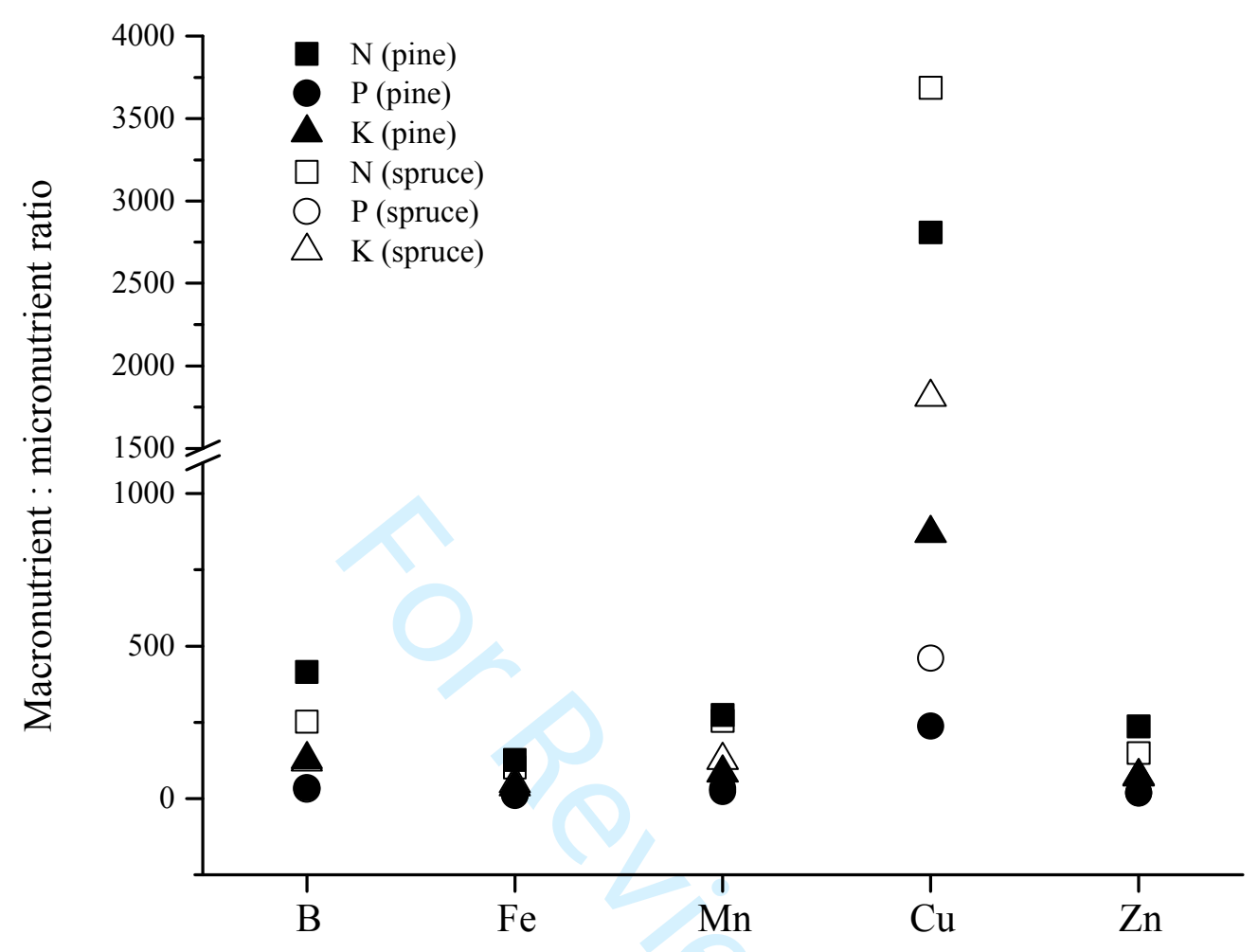

75

76 Figure 4. Ratios between foliar concentration of nitrogen, phosphorus and potassium and the 77 studied micronutrients $(\mathrm{B}, \mathrm{Fe}, \mathrm{Mn}, \mathrm{Cu}$ and $\mathrm{Zn})$ in lodgepole pine and white spruce.

78 